\title{
TESTING SUBSPECIES LIMITS IN MONARDELLA VILLOSA
}

\author{
A Thesis \\ presented to \\ the Faculty of California Polytechnic State University, \\ San Luis Obispo
}

In Partial Fulfillment

of the Requirements for the Degree

Master of Science in Biology

by

Taylor Crow

May 2013 
(C) 2013

Taylor Crow

ALL RIGHTS RESERVED 


\section{COMMITTEE MEMBERSHIP}

TITLE:

AUTHOR:

DATE SUBMITTED:

COMMITTEE CHAIR:

COMMITTEE MEMBER:

COMMITTEE MEMBER:
Testing Subspecies limits in Monardella villosa

Taylor Crow

May 2013

Dr. Matt Ritter, Associate Professor

Biological Sciences Department

Dr. David Keil, Professor Emeritus, Biological Sciences Department

Dr. Charles Knight

Biological Sciences Department 


\section{ABSTRACT \\ Testing Subspecies limits in Monardella villosa}

Taylor Crow

Several subspecies of Monardella villosa (California Coyote Mint) have been distinguished on the basis of leaf thickness, shape, and trichome characteristics, yet many intermediates are known. We investigated morphological differences in natural populations of two subspecies (M. v. subsp. villosa and $M$. v. subsp. franciscana) in the Scott Creek watershed, north of Davenport, in Santa Cruz County, CA. Monardella villosa subsp. franciscana grows in coastal scrub in gulches and ocean terraces whereas subsp. villosa grows at more protected inland sites. Morphological difference between subspecies may be adaptations to these different habitats. I grew plants in a common garden at Cal Poly, San Luis Obispo to determine if the morphological differences were genetically based. I also conducted a reciprocal transplant of the two subspecies between inland and coastal populations to determine if they are locally adapted.

The morphological differences (leaf hair density and length as well as leaf base angle) between subspecies were maintained in the common garden, yet no patterns of local adaptation were observed in germination or survival of the subspecies in reciprocal transplants in the first year. However, Monardella is a perennial plant and fitness differences may exist in later life stages that I have not yet measured.

Keywords: Reciprocal transplant, Monardella, Speciation, Morphology 


\section{ACKNOWLEDGMENTS}

I would like to thank the Wertman Foundation and the San Luis Obispo California Native Plant Society (SLO-CNPS) Chapter for their generous funding of this research.

This research would not have been possible without the undergraduates who helped in the set-up and monitoring of the transplant and morphological studies: Michelle Huang, Adrian Broz, Kendall Smith, Daniel Hernandez, Natalie Rossington and Adam Monkaba. I would also like to thank Jim West for his help collecting and leading inspiring field trips throughout Swanton Pacific Ranch.

A special thanks to my advisor Matt Ritter and committee members Dr. David Keil and Dr. Charlie Knight for their input and direction. And thanks to Jenn Yost who corrected and helped with statistics, experimental design and writing. 
$\begin{array}{lll}\text { Page } & \text { Paij }\end{array}$

List of Figures ................................................................................................. vii

Chapter

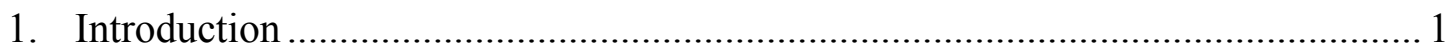

Materials and Methods ................................................................................ 3

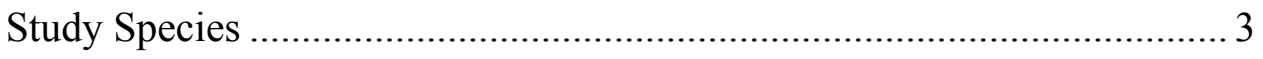

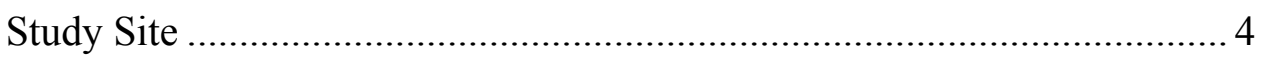

Greenhouse and Field Measurements .................................................... 6

Reciprocal Transplant Measurements .................................................. 9

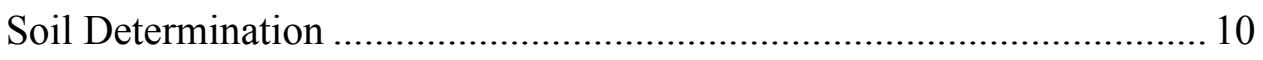

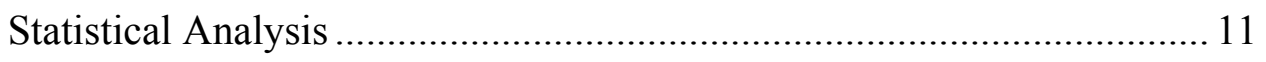

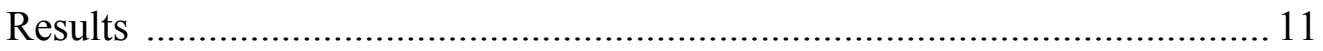

Survival Germination and Subspecies............................................... 14

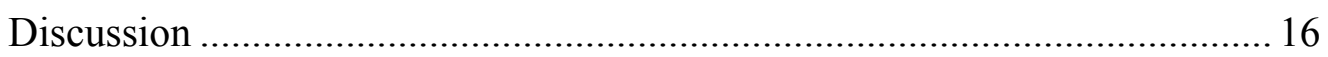

Morphological Plasticity in Wild and Greenhouse Plants ..................... 16

Reciprocal Transplant Discussion ..................................................... 18

Potential Future Studies ................................................................. 19

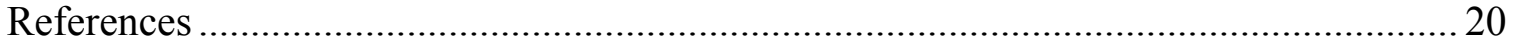

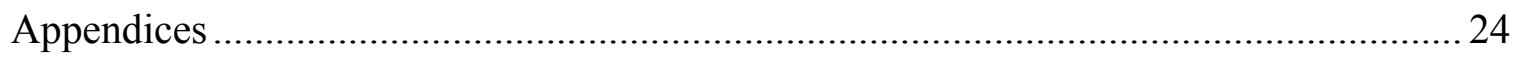

A: Seed collection location data....................................................... A2

B: Locations of plots used in experiment .......................................... A4

$\mathrm{C}$ : List of accessioned plants in Hoover Herbarium (OBI) ........................ A5

D: Population mean morphology measures .......................................... A6

E: Reciprocal transplant data........................................................... A 8

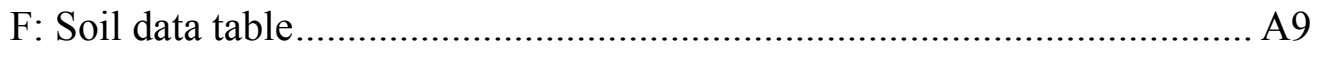

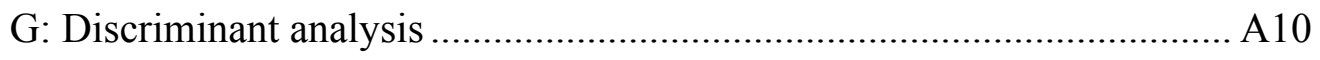




\section{LIST OF FIGURES}

Page

Figure 1: Map of common garden locations used in the reciprocal transplant and populations used in the experiments. ............................................... 5

Figure 2: A \& B): Images of the leaf surfaces of Monardella villosa subsp. villosa and Monardella villosa subsp. franciscana. C): Leaf base angle. D): pubescence characteristics of both subspecies adaxial and abaxial side..... 8

Figure 3: Greenhouse vs. field characteristics based on subspecies delineations ............. 13

Figure 4: Percent Germinated and alive by subspecies at different time points during

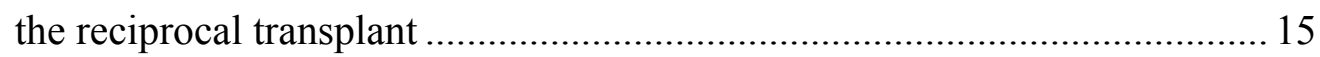

Figure 5: A) Germination and B) survival of Monardella villosa at inland and coastal

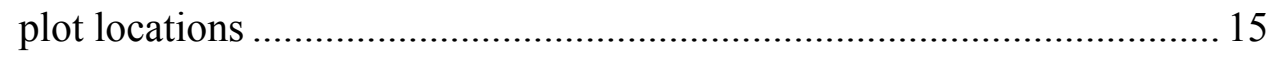




\section{Chapter 1}

\section{INTRODUCTION}

The foundation of taxonomy, a science concerned with description, identification, nomenclature and classification, is in the patterns of similarities and differences. The acorns of an oak, the legume of a pea, the fragrance of a mint and the cone of a conifer help us group together large number of species based on shared characteristics, or synapomorphies. There are groups, however, in which morphology is difficult to interpret. This can be due to a lack of morphological variation, highly variable morphology within species, or convergence on similar morphologies. Groups of organisms that cannot be easily classified based on their morphology have been problematic for taxonomist to assign names based on their evolutionary relationship.

The genus Monardella Benth. is diverse and widespread in California, with over 30 species and 50 taxa recognized (Elvin and Sanders, 2009). Diverse morphology within and between taxa combined with a wide range of climate and soil habitats make this group taxonomically difficult (Sanders et al., 2012). The generally terminal clustered cyme (glomerule), made of flowers with 5 lobed corollas, 4 stamens and subtended by a whorl of bracts distinguish Monardella from other Genera in Lamiaceae. Plant pubescence, habit, bract morphology and annual vs. perennial life cycles all help distinguish species within Monardella. The highly variable morphology for each of these characters has resulted in taxonomic uncertainty often with many synonyms for one taxon. The difficulty in interpreting the morphology of Monardella could be because the 
genus is a recent radiation in California. Preliminary genetic analyses on Monardella have revealed little variation in inter-transcribed spacer (ITS) sequences, estimated to be less than 5 mya (Prince, 2009).

Monardella villosa Benth. is one of the variable species in the genus, with subspecies: franciscana, obispoensis and villosa currently recognized (Sanders et al., 2012). The subspecies have been recognized based on differences in pubescence characteristics and leaf shape. Two subspecies, Monardella villosa subsp. franciscana (Elmer) Jokerst and M. v. subsp. villosa grow closely together in the coastal ranges from Monterrey to Mendocino county, CA. Monardella v.f. usually grows in terraces and gulches adjacent to the coast, whereas subsp. villosa typically grows at more inland sites. Monardella villosa subsp. franciscana has thick triangular leaves that are often wooly pubescent abaxially, which distinguishes it from subsp. villosa which has thinner leaves with an obtuse leaf base angle (Sanders et al., 2012).

In this study I investigated the genetic basis of phenotypic variation between subsp. villosa and franciscana in California. I conducted a greenhouse common garden and a field reciprocal transplant experiment to test whether the morphological differences are genetically based and adaptive in their local habitats. Phenotypic measurements were made on wild and greenhouse grown plants to test for morphological plasticity. Germination and survival were measured for 16 months in a reciprocal transplant to test for any adaptive divergences between populations.

I hypothesize that the differences in morphological characters recognized in Monardella villosa are genetically based, and adaptive to their niche environments. If these two subspecies have different morphologies due to selection in different but 
adjacent habitats, I have the opportunity to study how early divergence might ultimately lead to speciation. I set up a reciprocal transplant to study this adaptive hypothesis.

The basis for determining local adaptation of intraspecific taxa is accomplished by comparing fitness measures of local and immigrant genotypes in each other's habitat. Local adaptation can be quantified by comparing the germination, survival, flowering and seed set along with other ecological interactions, such as herbivory and pollinator visitation, in a reciprocal transplant. Strict local adaptation can be determined if the local form does better relative to the immigrant in both experimental sites. A lesser degree of local adaptation is measured if taxa do better in their local habitat relative to the away habitat, but not better in their local habitat relative to the foreign plants (reviewed in Sobel et al., 2010).

\section{MATERIALS AND METHODS}

\section{Study Species}

Monardella villosa (Lamiaceae) was described by George Bentham(1844)based on a collection from Bodegas, CA. The current taxonomic treatment recognizes 3 subspecies found in western California from Santa Barbara County to Oregon (Sanders et al., 2012). The species is a subshrub, perennial, with glomerule inflorescences that flower from late spring to early summer. Monardella villosa subsp. villosa, subsp. fraciscana, and obispoensis differ in leaf shape and pubescence characteristics. Subspecies franciscana has a more triangular leaf shape, truncate leaf base, and typically more abaxially woolypubescent leaf surface than subsp. villosa (Jokerst, 1992) (Figure 2). Monardella villosa subsp. obispoensis is distinguished from the other two by the abundant branched trichomes on the abaxial leaf surface. Monardella villosa subsp. villosa has the largest 
range distributed from the Klamath range in northern California throughout the inner and outer coast ranges to Santa Barbara County. Subspecies franciscana occurs from the north coast through the central coast regions near the ocean. Finally, subspecies obispoensis occurs in the central coast region (Sanders et al., 2012). These regions follow the region designations of the Jepson Manual (Baldwin et al., 2012)

\section{Study Site}

Swanton Pacific Ranch, approximately fourteen miles north of Santa Cruz along Highway 1, encompasses 3200 acres donated to Cal Poly in 1993 by Al Smith (Dietterick, 2011). The ranch property contains over 12\% of California's native and introduced flora, including many rare and endangered taxa (West, 2013). The ranch is also diverse geologically with more than 26 soil map units (Staff, 2013). Scotts Creek and its tributaries flow through the ranch property creating many riparian and wetland areas. The ranch has evergreen forests of Douglas fir, coast redwood, California nutmeg, and Monterey pine; mixed evergreen forest with Shreve oak, coast live oak, Tan-bark oak, California Buckeye, and California Bay. The ranch also contains grasslands, coastal scrub, and chaparral and spans elevationally from sea level to over 1,000 feet. Both subsp. villosa and franciscana occur on Swanton Pacific Ranch (Figure 1). 


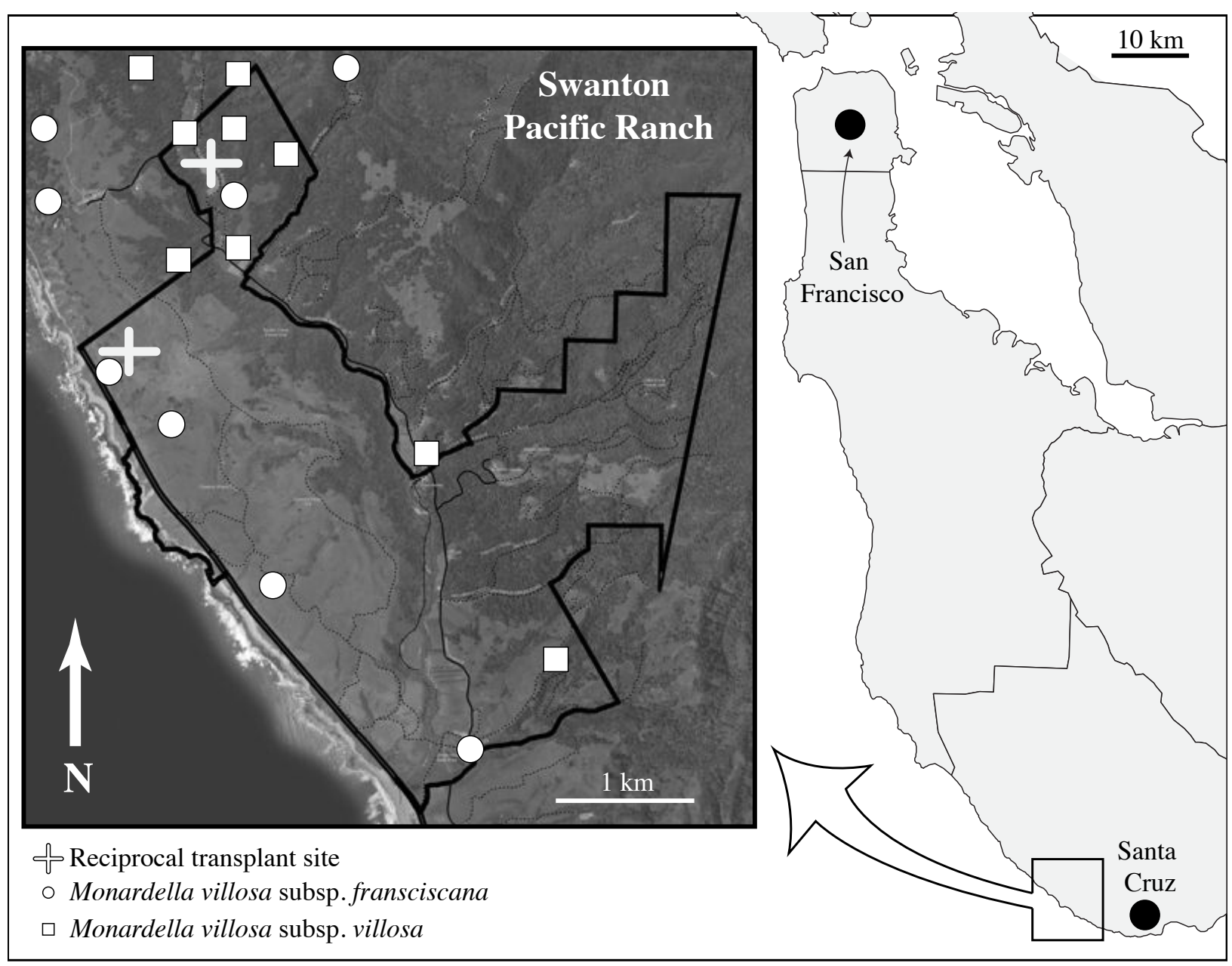

Figure 1: Map of common garden locations used in the reciprocal transplant and populations used in the experiments. 


\section{Greenhouse and Field Measurements}

Seeds were collected by Mr. Jim West in the summer of 2011 from locations on and around Swanton Pacific Ranch property. Twenty-five separate seed collection represent the 17 populations. Seed collection locations, dates, and site descriptions are in appendix A.

Seeds used in the greenhouse common garden were stratified in moist petri dishes in a 2 degree celsius refrigerator and planted in a 1:1:1 peat, perlite and sand mix in 4" pots at Cal Poly's plant conservatory greenhouse. I watered plants for 10 minutes four times a week, and reduced to three times per week upon germination. I separated the seedlings into individual 4" pots before they reached 2.5 inches, and watering was further reduced to twice a week to keep plants alive.

The plants grown in the greenhouse were used for two purposes. First I measured leaf pubescence and leaf base angle of each population using two mature expanded leaves from separate nodes of three different plants. I used the remaining plants grown in the greenhouse for a second reciprocal transplant on Swanton Pacific Ranch for future experimentation (Data not shown here).

I also measured leaf shape and pubescence from native populations on Swanton Pacific Ranch and compared them with the greenhouse grown plants to determine the genetic basis and plasticity of traits. I chose plants from all populations of the original seed collection on January $12^{\text {th }}, 2013$ for the field morphological measures. One branch from each individual in a population was collected. I randomly chose three branches per population and measured leaf base angle, trichome density and hair length on two mature leaves from two separate nodes per branch. After I made morphological measurements on 
the wild specimens I pressed and accessioned the plants into the Hoover Herbarium (OBI) on the Cal Poly campus (Appendix C).

I measured leaf base angle by the angle between the petiole and leaf base (Figure 2). I measured leaf hair density, on both adaxial and abaxial surfaces, by taking a leaf punch, counting the trichomes and dividing the total number by the area of $28.27 \mathrm{~mm}^{2}$. Leaf hair length was recorded by measuring three trichomes found on expanded leaf tissue of each sample and recording the average. Elevational data and distance from shore measurements were made using Google Earth. 


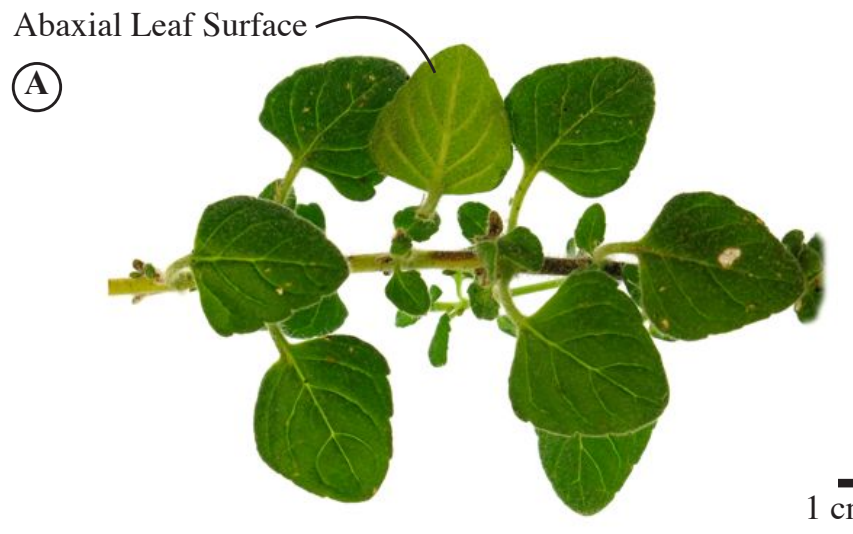

Monardella villosa subsp. franciscana

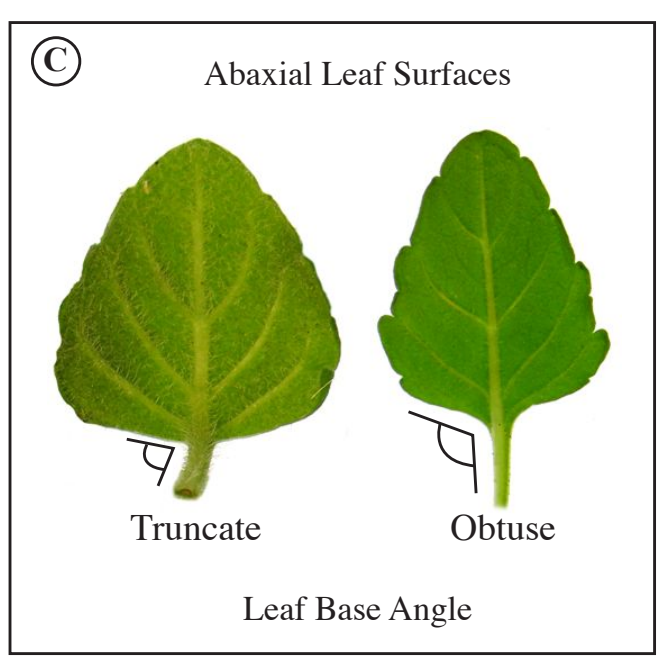

(D)
(B)

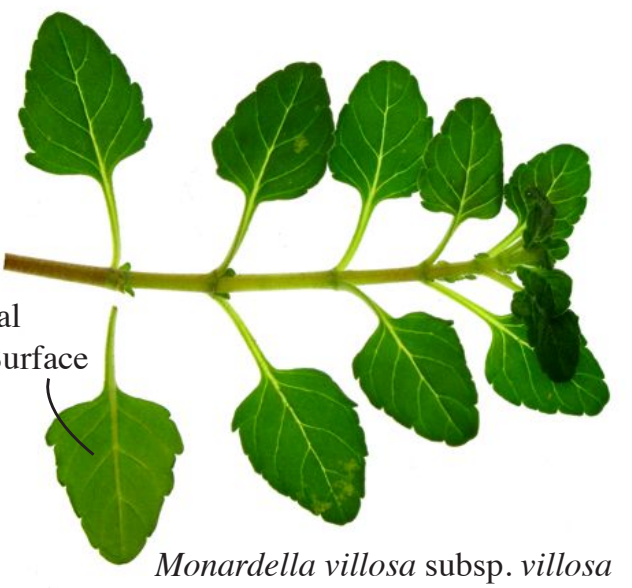

Adaxial

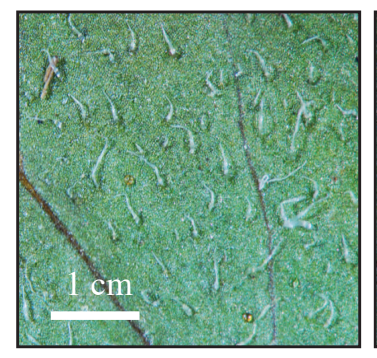

Abaxial

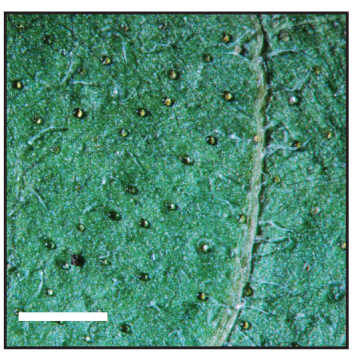

Monardella villosa subsp. villosa
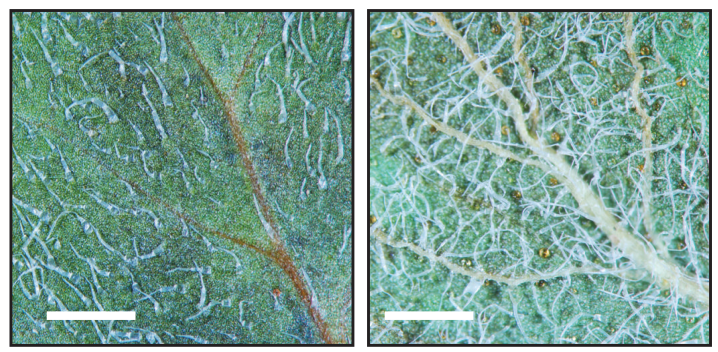

Monardella villosa subsp. franciscana

Figure 2: A \& B): Images of the leaf surfaces of Monardella villosa subsp. villosa and Monardella villosa subsp. franciscana. C): Leaf base angle. D): pubescence characteristics of both subspecies adaxial and abaxial side. 


\section{Reciprocal Transplant Measurements}

I chose the plots for the reciprocal transplant to represent suitable habitat for Monardella and installed them near natural populations. The plots found at the inland site represent common habitat for subsp. villosa are found along RW Pozzi Ranch Road on Swanton Ranch. These inland plots are numbered one through four and can be found on the west facing slope located on the east side of Pozzi Road. Plots one and two occur on an exposed slope near the forest margin in a sunny location approximately 10 meters from each other. Plots three and four are approximately 200 meters north along Pozzi Road on a slope near a forest margin in a much more shaded area. I numbered the coastal plots representing common subsp. franciscana habitat five through eight located in Big Willow gulch on the western terraces of Swanton Pacific Ranch approximately two kilometers west from the inland plots. The plots are on the north facing slope of Big willow Gulch spaced approximately ten meters from each other (Appendix B).

The same seed collections used in the greenhouse common garden were also used in the reciprocal transplant study at Swanton Pacific Ranch. I glued forty individual seeds from each seed source collection to toothpicks using Elmer's wood glue. I spray painted the toothpicks different color combinations to distinguish each plant family for census observations. I designed the plots using a random number generator with 5 seeds per seed source collection (1000 total) assigned to each of eight plots, four inland and four coastal (Figure 1). Rebar, chicken wire and light gauge wire were used to build cages to discourage herbivory by deer, cattle or other small mammals. I also drove T-posts around the coastal plots to deter cattle from trampling each plot.

The seeds in the reciprocal transplant were planted in November of 2011. The 
location of each seed was assigned randomly and resulted in a $12 \times 11$ grid that was .75 meter wide and $1 \mathrm{~m}$ long. I censused the seeds every 1-2 months to determine germination and survival success until March 1,2013. The use of marked toothpicks greatly increased the accuracy of census dates, as the colors were used to double check the identity of each maternal family. On the last census date I marked the remaining plants with a permanent metal scratch label for ease of future work.

\section{Soil Determination}

The USDA's Natural Resources Conservation Service has conducted numerous soil surveys throughout the country and makes these data available at no cost to the public. Soils data for all of Santa Cruz County were imported to the map document and polygons were created based on the various soil types listed in the attribute table. As with slope and aspect, the intersect tool was used on the population's coordinate layer to determine which soil type each population had present at its site.

To determine the soils that each subspecies was associated with I collected coordinate information using a Garmin GPS unit of populations of Monardella throughout Swanton Pacific Ranch. Coordinates were imported into ArcMap 10.1 as a separate layer. A digital elevation model (DEM) was obtained from Cal Poly's data services (G drive) and imported to the map document. The DEM had an accuracy of $1 \mathrm{~m} 2$. The aspect tool was used to create a layer of 9 different polygon types representing the following aspects: flat, N, NE, E, SE, S, SW, W, and NW. The slope tool was also applied to create a layer containing 14 different polygon types representing the following slopes: $0,5,10,15,20,25,30,35,40,45,50,55,60$, and 65 degrees. The intersect tool was then used on the coordinate layer to determine which polygon type in both the aspect 
and slope layers that each populations point fell within. From this I found corresponding aspect, slope data and soil type for each population in our study area.

\section{Statistical Analysis}

To determine the environmental and genetic influences on traits I compared morphological measurements between field collected and greenhouse grown specimens (Appendix D). I compared the trait values of greenhouse and field measurements using a one way comparison of means in JMP (JMP, Ver 10.0 SAS Institute Inc., Cary, North Carolina, USA). This generated T-values to determine significance of difference between means and were graphed in JMP.

I analyzed the reciprocal transplant data in excel and JMP. The percentage alive for each census date value was calculated as the number germinated and alive in the transplant divided by the total number of seeds planted for each population. Survival was calculated by taking the number alive per population and dividing it by the total number of seeds that germinated. I then compared these by using a one way comparison of means to determine significance using a student's t-test.

I double checked the subspecies circumscription of populations using a discriminant analysis using the leaf base angle, pubescence density and trichome length of each population on JMP (Appendix G). The results all agreed except for population 15, so I chose the circumscription result using the greenhouse data.

\section{RESULTS}

I found that across all traits measured in the greenhouse and field collected specimens, the significant differences found in the field between subspecies remained significantly different in the greenhouse (Figure 3). Monardella villosa subsp. 
franciscana has longer trichomes on the adaxial and abaxial leaf surface, has a greater trichome density on the abaxial leaf surface, and has a more truncate leaf base angle than subsp. villosa. There is no difference in hair density on the adaxial leaf surface between the subspecies in the field, but in the greenhouse subsp. franciscana had significantly higher adaxial hair density than subsp. villosa (Figure 3).

There is a significant $(\mathrm{P}<.05)$ difference between the subspecies distance from the ocean. On average, subsp. franciscana grew closer to the shoreline than subsp. villosa. Monardella $v$. v. had a significantly larger angle between the petiole and leaf base than M. v. f., and this difference was maintained in the greenhouse. Leaf hair length is significantly longer on the adaxial and abaxial surface of subsp. franciscana $(\mathrm{P}<.0001)$, and the greenhouse and wild measurements remained unchanged within both subspecies. Leaf hair density on the adaxial surface between subspecies in the field were not significantly different, however, in the greenhouse, subsp. franciscana had a much higher leaf hair density than the field measurements while subsp. villosa remained the same. Leaf hair density on the abaxial surface of subsp. franciscana was higher $(\mathrm{P}<.0001)$ in field and greenhouse measurements. The plants grown in the greenhouse had much higher leaf hair density than in the wild $(\mathrm{P}<.0001)$ (Figure 3 ). 

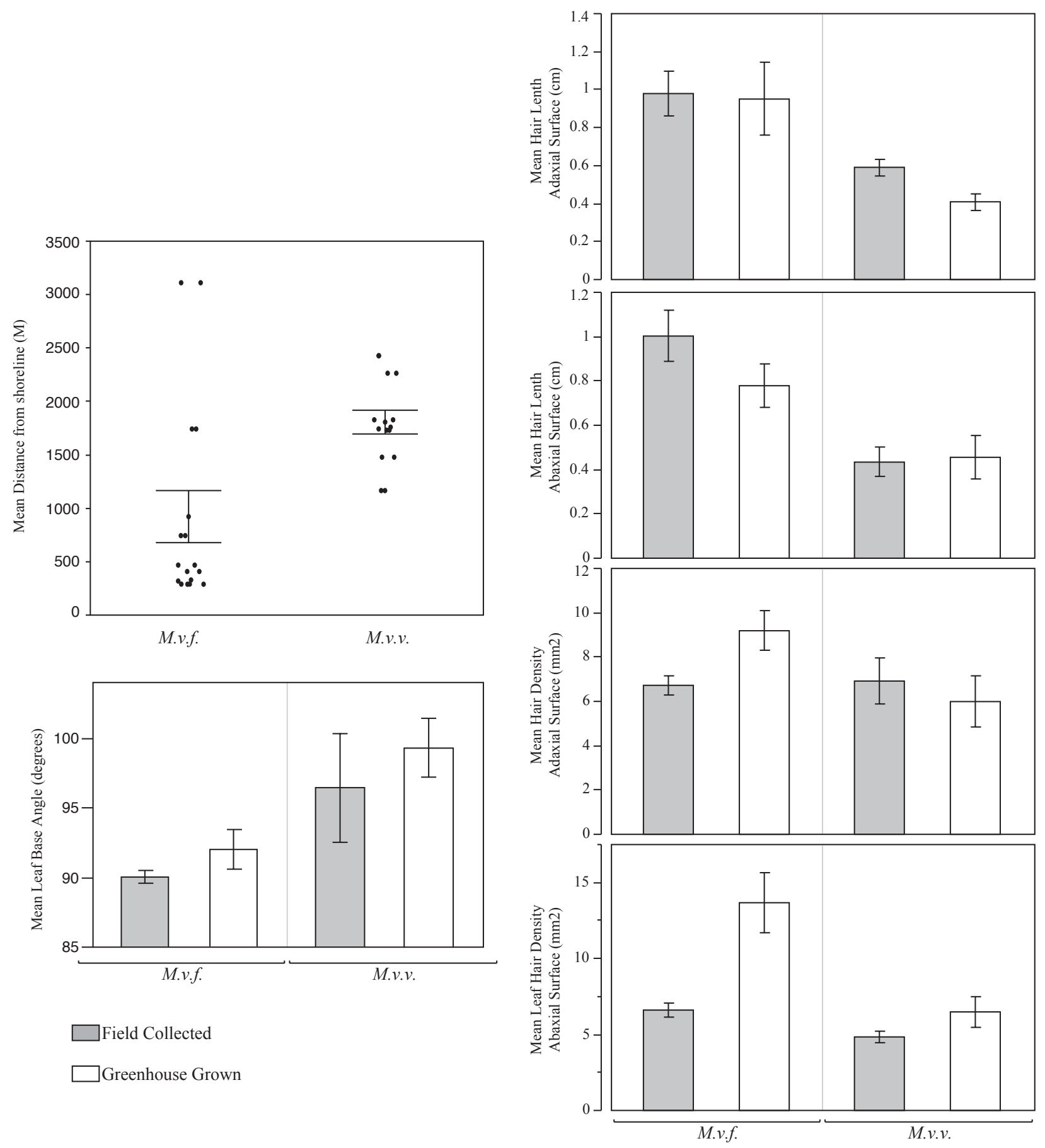

Figure 3: Greenhouse vs. field characteristics based on subspecies delineation.

A) Distance from ocean. B) Leaf base angle. C) Adaxial leaf hair length. D) Abaxial leaf hair length. E) Adaxial leaf hair density. F) Abaxial leaf hair density 


\section{Survival, Germination and Subspecies}

There was no difference in germination and survival between subspecies in the reciprocal transplant at any census collection at either location (Appendix E). The population means were measured as a percent alive of total seeds planted. Germination peaked in February and March of 2012 at both sites, while the most dramatic seedling mortality occurred from June through September of 2012 (Figure 4).

Difference in germination of subspecies between locations was significant for both subsp. villosa and subsp. franciscana. Germination was significantly higher at the coastal site $(\mathrm{P}<.0014)$. Survival at the inland site was significantly higher than at the coastal location for both subspecies $(\mathrm{P}<.05)$ (Figure 5). This indicate a harsher environment for young plants immediately adjacent the ocean. 

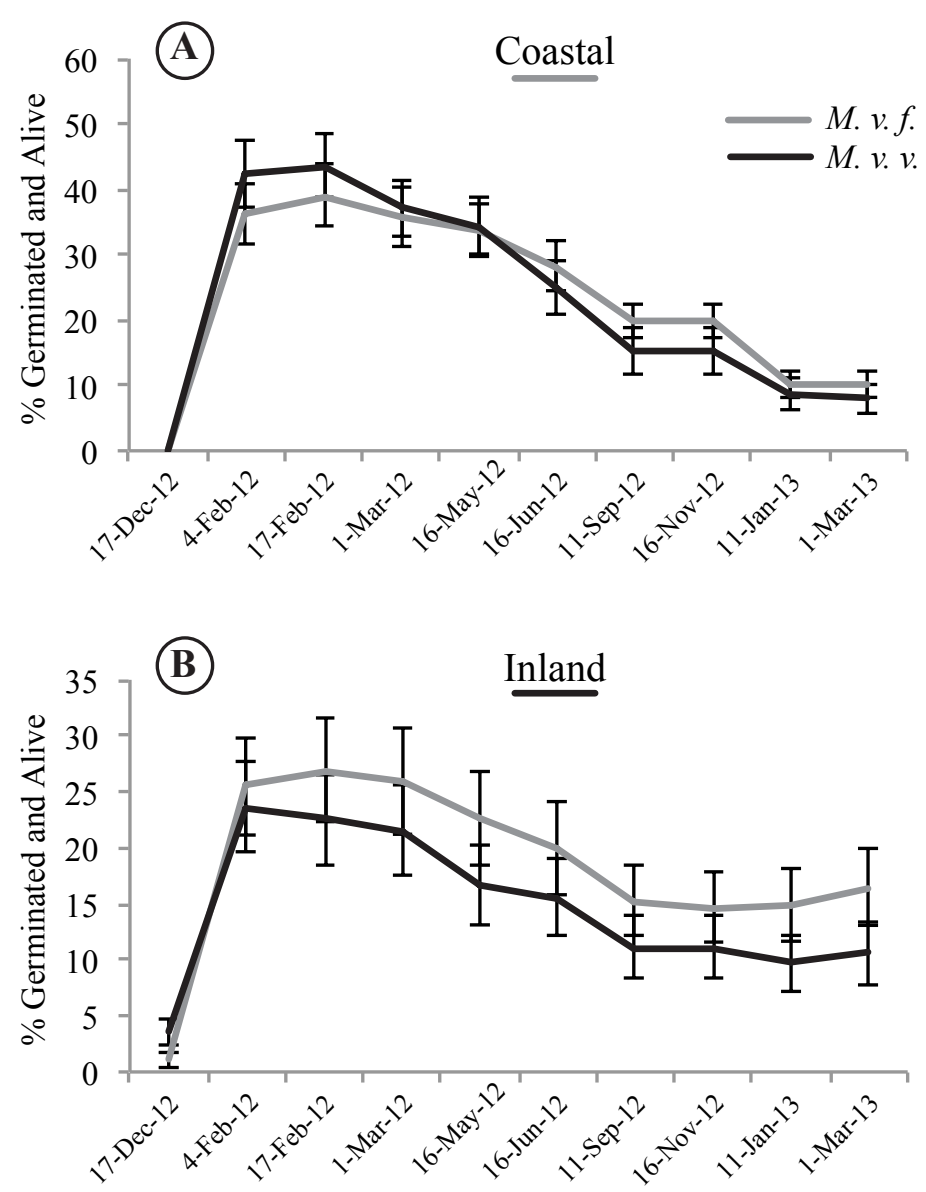

Figure 4: Percent germinated and alive by subspecies at different time points during the reciprocal transplant
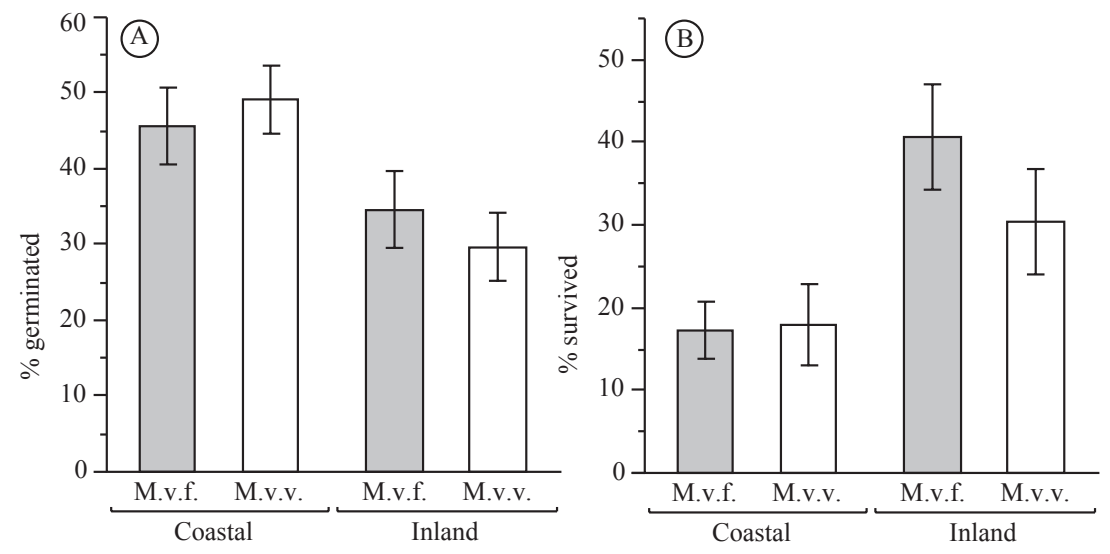

Figure 5: A) Germination and B) survival of Monardella villosa at inland and coastal plot locations 


\section{DISCUSSION}

This study has shown that populations of Monardella villosa, hypothesized to represent two subspecies in the Santa Cruz area, have genetically based differences for leaf hair length, abaxial trichome density and leaf base angle. This shows that populations on Swanton Pacific Ranch have genetic differences that determine distinct morphologies of the two subspecies. However, these characters do not appear to be adaptive in the different environments for germination or early life survival. The successful establishment of subspecies in both their 'home' and 'away' environments means that no barriers have evolved to block either subspecies from germinating or surviving the first year and a half of their life in habitats where the other subspecies occur. Therefore, the distribution of the two subspecies cannot be explained by what I measured. Results of the reciprocal transplant indicated that both subspecies of $M . v$. survived better at inland sites, suggesting a harsher habitat at the immediate coastal habitats.

\section{Morphological Plasticity in Wild and Greenhouse Plants}

Genetically based variations in leaf characters could mean there is an adaptive divergence (Housman et al., 2002). I found that differences in morphologies measured on field collected plants remained unchanged when plants were grown in a common garden except adaxial trichome density. This suggests that most of the phenotypic variation between populations on Swanton Pacific Ranch are genetically based, whereas trichome

density is environmentally plastic (Figure 3). Leaf trichome density and length have been shown to affect transpiration rate and gas exchange across diverse lineages of plants (Brewer et al., 1991).

Brewer et al. (1991; 1997) have shown that leaf pubescence density can affect the 
frequency and duration of water on leaf surfaces (leaf wetness). Increased leaf wetness has been shown to negatively affect plants by decreasing photosynthetic rate (Ishibashi and Terashima, 2006), increasing disease susceptibility (Doss et al., 1987; Hartman et al., 1999), and decreasing growth rate (Tullus et al., 2012). The hairier subspecies franciscana typically found near the coast could be an adaptive divergence in response to the coastal fog influence. The longer and more dense trichomes of subsp franciscana could hold the water droplets further away from the leaf surface, allowing for gas exchange to occur through stomata, and increase transpiration. The hairs may also function in UV protection (Choinski and Wise, 1999) and/or creating a boundary layer decreasing the rate of water loss (Ehleringer and Mooney, 1978).

Leaf trichome production may also have associated costs (Mauricio, 1998). In a study of Arabidopsis kamchatica in Alaska the more glabrous populations produced significantly more fruit than the pubescent populations, showing a selection for glabrousness (Steets et al., 2010). The reduced trichome density and length may benefit subsp. villosa in a similar fashion. Adaxial leaf hair density was not significantly different in field collected specimens, but subsp. franciscana had significantly higher trichome density in greenhouse grown specimens (Figure 3). This shows that adaxial leaf hair density may be more plastic than other features. Leaf hair density has been implicated in several adaptive studies (Björkman et al., 2008; Steets et al., 2010), and the environmental plasticity may allow this early to mid successional species a higher survival rate in the heterogenous environments it is found in. 


\section{Reciprocal Transplant Discussion}

Local adaptation was not detected in my reciprocal transplant study of $M . v$.

Germination and survival did not differ between subspecies at the coastal or inland plots. The morphological differences found to be genetically based, did not correlate with a higher germination or survival for either subspecies. However, these measurements are only part of the plants life cycle, and local adaptation may be measured in another life stage. The question remains, why are there different forms of $M . v$. on Swanton Pacific Ranch? And why do they occur where they do? If there is no selection keeping the subspecies distinct, why isn't the homogenizing effect of gene flow creating a more morphologically similar set of populations?

The percentage of plants that germinated at the coast was higher, perhaps due to the increased moisture brought in by the maritime fog. The inland plants tended to survive better, likely due to the more loamy soils at inland sites relative to the sandier bonnydoon soils of the coastal site (Appendix F). The harsher, windier conditions of the coast may also have played a role in the reduced survival of plants in the common gardens. This pattern of higher seedling mortality at the coast may play more of a role in local adaptation in later life stages by affecting the flowering and seed success of each subspecies.

The distributional pattern of $M . v$. may have alternate explanations. The prevailing winds on Swanton Pacific Ranch from the Northwest may allow seeds of $M . v \cdot f$. to move inland, while blocking M. v. v. from migrating to the immediate coastal environments. The calyx of $M . v$. is persistent in fruit, and become dried, scarious and reflexed which I speculate may function in wind dispersal of seed in this species. The distribution of these 
subspecies may also be based on a historical or novel selection pressures such as extinct herbivores or recently introduced pests (Eastman et al., 2009).

While local adaptation hypotheses are commonly used to explain distributional patterns, studies showing strict local adaptation are not found a majority of the time (Leimu and Fischer, 2008). Local adaptation can be hindered by gene flow. If new suites of genes enter a population that are undergoing selection, the result can be a loss of specialization at the genetic and phenotypic levels (Kawecki and Ebert, 2004; reviewed in McKay et al., 2005). Because of the close proximity of these subspecies on Swanton Pacific Ranch gene flow is likely to occur and introgression a possibility.

\section{Potential Future Studies}

Two reciprocal transplants are now in place on Swanton Pacific Ranch, and future students will have the opportunities to study other potential selection pressures keeping subsp. villosa and subsp. franciscana apart. These pressures may include survival, pollinator bias, flowering success, hybrid viability, and seed set. There is a difference in odor between the two subspecies that warrants further investigation. Several undergraduates have committed to continue observation and data collection of the reciprocal transplant plots. 


\section{References}

Baldwin, B.G., D.H. Goldman, D.J. Keil, R. Patterson, T.J. Rosatti, andf D.H. Wilken, editors. 2012. The Jepson manual: vascular plants of California, second edition. University of California Press, Berkeley.

Bentham, G., S.E. Belcher, and G.B. Admiralty. 1844. The botany of the voyage of H.M.S. Sulphur. London: Smith, Elder,1844-[46].

Björkman, C., P. Dalin, and K. Ahrné. 2008. Leaf trichome responses to herbivory in willows: induction, relaxation and costs. New Phytologist 179: 176-184.

Brewer, C.A., and W.K. Smith. 1997. Patterns of leaf surface wetness for montane and subalpine plants. Plant, Cell \& Environment 20: 1-11.

Brewer, C.A., W.K. Smith, and T.C. Vogelmann. 1991. Functional interaction between leaf trichomes, leaf wettability and the optical properties of water droplets. Plant, Cell \& Environment 14: 955-962.

Choinski, J.S., Jr, and R.R. Wise. 1999. Leaf Growth Development in Relation to Gas Exchange in Quercus marilandica Muenchh. Journal of Plant Physiology 154: 302-309.

Dietterick, B. 2011. Swanton Pacific Ranch Management Plan. http://www.spranch.org/files/2011SPRManagement\%20Plan_v4_111025. pdf

Doss, R.P., C.H. Shanks, J.D. Chamberlain, J.D. Garth. 1987. Role of leaf hairs in 
resistance of a clone of Beach Strawberry, Fragaria chiloensis, to feeding by adult black vine weevil, Otiorhynchus sulcatus (Coleoptera: Curculionidae). Environmental Entomology 16: 764-768.

Eastman, J.M., J.H. Niedzwiecki, B.P. Nadler, and A. Storfer. 2009. Duration and consistency of historical selection are correlated with adaptive trait evolution in the streamside salamander, Ambystoma barbouri. Evolution 63: 2636-2647.

Ehleringer, J.R., and H.A. Mooney. 1978. Leaf hairs: effects on physiological activity and adaptive value to a desert shrub. Oecologia 37: 183-200.

Elvin, M.A., and A.C. Sanders. 2009. Nomenclatural Changes for Monardella (Lamiaceae) in California. Novon: A Journal for Botanical Nomenclature 19: 315-343.

Hartman, J.R., L. Parisi, and P. Bautrais. 1999. Effect of leaf wetness duration, temperature, and conidial inoculum dose on apple scab infections. Plant disease 83: 531-534.

Housman, D.C., M.V. Price, and R.A. Redak. 2002. Architecture of coastal and desert Encelia farinosa (Asteraceae): consequences of plastic and heritable variation in leaf characters. American journal of botany 89: 1303-1310.

Ishibashi, M., and I. Terashima. 2006. Effects of continuous leaf wetness on photosynthesis: adverse aspects of rainfall. Plant, Cell \& Environment 18: $431-438$. 
Jokerst, J. 1992. Nomenclatural changes in California Monardella (Lamiaceae). Phytologia 72: 9-16.

Kawecki, T.J., and D. Ebert. 2004. Conceptual issues in local adaptation. Ecology Letters 7: $1225-1241$.

Leimu, R., and M. Fischer. 2008. A Meta-Analysis of Local Adaptation in Plants. PloS one 3: e4010.

Mauricio, R. 1998. Costs of Resistance to Natural Enemies in Field Populations of the Annual Plant Arabidopsis thaliana. The American naturalist 151: 20-28.

McKay, J.K., C.E. Christian, S. Harrison, and K.J. Rice. 2005. “How Local Is Local?” A Review of Practical and Conceptual Issues in the Genetics of Restoration. Restoration Ecology 13: 432-440.

Prince, L.M. 2009. The relationship of Monardella viminea to closely related taxa based on analyses of ISSRs. Rancho Santa Ana Botanical Gardens.

Sanders, A.C., M.A. Elvin, M.S. Brunell. 2012. Monardella villosa in Jepson Flora Project (eds.) Jepson eFlora, http://ucjeps.berkeley.edu/cgibin/get IJM.pl?tid=51628. Accessed on May, 23, 2013.

Sobel, J.M., G.F. Chen, L.R. Watt, and D.W. Schemske. 2010. The Biology of Speciation. Evolution 64: 295-315.

Staff, S.S. 2013. Custom Soils Report for Santa Cruz County, California. USDA.

Steets, J.A., N. Takebayashi, J.M. Byrnes, and D.E. Wolf. 2010. Heterogeneous selection 
on trichome production in Alaskan Arabidopsis kamchatica

(Brassicaceae). American journal of botany 97: 1098-1108.

Tullus, A. et al. 2012. Climate Change at Northern Latitudes: Rising Atmospheric

Humidity Decreases Transpiration, N-Uptake and Growth Rate of Hybrid Aspen M. Bennett [ed.],. PloS one 7: e42648.

West, J.A. 2013. Traversing Swanton Road. www.arboretumucsc.edu 


\section{APPENDICES}
A. Seed collection location data
B. Locations of plots used in experiment
C. List of accessioned plants in Hoover Herbarium (OBI)
D. Population mean morphology measures
E. Reciprocal transplant data
F. Soil data table
G. Discriminant analysis 


\section{APPENDIX A}

Seed collection location

\begin{tabular}{|c|c|c|c|c|}
\hline $\begin{array}{l}\text { Family } \\
\text { \# }\end{array}$ & Population & Species & Date & GPS \\
\hline 1 & 4 & M.v.f & $10 / 17 / 11$ & $37^{\circ} 03^{\prime} 56.36^{\prime \prime N} / 122^{\circ} 15^{\prime} 08.90^{\prime \prime W}$ \\
\hline 2 & 3 & M.v.f & $9 / 27 / 11$ & $37^{\circ} 04^{\prime} 14.10^{\prime \prime N} / 122^{\circ} 15^{\prime} 19.27^{\prime \prime W}$ \\
\hline 3 & 4 & M.v.f & $10 / 17 / 11$ & $37^{\circ} 03^{\prime} 56.36^{\prime \prime N} / 122^{\circ} 15^{\prime} 08.90^{\prime \prime W}$ \\
\hline 4 & 17 & M.v. & $10 / 5 / 11$ & $37^{\circ} 04^{\prime} 41.94^{\prime \prime} \mathrm{N} / 122^{\circ} 15^{\prime} 00.09^{\prime \prime W}$ \\
\hline 5 & 14 & M.v. & $10 / 11 / 11$ & $37^{\circ} 05^{\prime} 09.54^{\prime \prime N} / 122^{\circ} 14^{\prime} 47.95^{\prime \prime W}$ \\
\hline 5 & 14 & M.v. & $10 / 11 / 11$ & $37^{\circ} 05^{\prime} 01.42^{\prime \prime} \mathrm{N} / 122^{\circ} 14^{\prime} 46.38^{\prime \prime W}$ \\
\hline 6 & 8 & M.v.v. & $10 / 15 / 11$ & $37^{\circ} 05^{\prime} 14.65^{\prime \prime} \mathrm{N} / 122^{\circ} 14^{\prime} 54.81^{\prime \prime W}$ \\
\hline 7 & 6 & M.v.f. & $9 / 27 / 11$ & $37^{\circ} 02^{\prime} 32.48^{\prime \prime N} / 122^{\circ} 13^{\prime} 19.78^{\prime \prime W}$ \\
\hline 8 & 13 & M.v. & $9 / 24 / 11$ & $37^{\circ} 05^{\prime} 44.55^{\prime \prime N} / 122^{\circ} 14^{\prime} 12.98^{\prime \prime W}$ \\
\hline 9 & 8 & M.v.v. & $9 / 24 / 11$ & $37^{\circ} 05^{\prime} 13.78^{\prime \prime N} / 122^{\circ} 14^{\prime} 55.44^{\prime W}$ \\
\hline 10 & 13 & M.v. & $9 / 24 / 11$ & $37^{\circ} 05^{\prime} 41.88^{\prime \prime N} / 122^{\circ} 14^{\prime} 17.51^{\prime \prime W}$ \\
\hline 11 & 15 & M.v. & $9 / 23 / 11$ & $37^{\circ} 05^{\prime} 08.32^{\prime \prime N} / 122^{\circ} 14^{\prime} 26.65^{\prime W}$ \\
\hline
\end{tabular}

Elv.

(M) Description

271 China ladder Gulch (WF)

308 Big Willow gulch (WF)

271 China ladder Gulch (WF)

339 Scotts Creek (EF) Buckeye ridge

299 Scotts Creek /Schoolhouse ridge complex

197 Scotts Creek /Schoolhouse ridge complex

148 Scotts Creek Ws/Wf RB over purdy rd by slid

70 Scotts creek/ WF brushy slope near casa ver

770 Scotts creek/EF slope near seymore field

148 Scotts Creek/Purdy rd, near slide

933 Scotts Creek/Top of seymore hill/SF

499 Scotts Creek/Schoolhouse ridge/Mill crk side 
3 M.v.f $\quad 9 / 21 / 11 \quad 37^{\circ} 04^{\prime} 13.87^{\prime \prime N} / 122^{\circ} 15^{\prime} 21.31^{\prime \prime W}$

12 M.v. $\quad 9 / 24 / 11 \quad 37^{\circ} 05^{\prime} 49.77^{\prime \prime N} / 122^{\circ} 14^{\prime} 52.00^{\prime \prime W}$

10 M.v.v

$9 / 27 / 11$

$37^{\circ} 03^{\prime} 52.45^{\prime \prime} \mathrm{N} / 122^{\circ} 13^{\prime} 39.60^{\prime \prime} \mathrm{W}$

11 M.v.v.

$10 / 13 / 11$

$37^{\circ} 02^{\prime} 57.21^{\prime \prime N} / 122^{\circ} 12^{\prime} 51.76^{\prime \prime} \mathrm{W}$

5 M.v.f

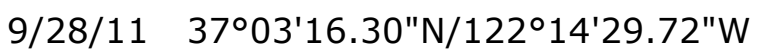

17 M.v.

$10 / 4 / 11 \quad 37^{\circ} 04^{\prime} 44.90^{\prime \prime N} / 122^{\circ} 14^{\prime} 58.41^{\prime \prime} \mathrm{W}$

17 M.v.

$10 / 4 / 11$

$37^{\circ} 04^{\prime} 44.41^{\prime \prime} \mathrm{N} / 122^{\circ} 15^{\prime} 00.43^{\prime \prime} \mathrm{W}$

1 M.v.f.

9/30/11 37०05'12.57"N/122 $15^{\prime} 56.16^{\prime \prime W}$

16 M.v.

$10 / 11 / 11 \quad 37^{\circ} 05^{\prime} 09.54^{\prime \prime N} / 122^{\circ} 14^{\prime} 47.95^{\prime \prime} W^{*}$

16 M.v.

$10 / 11 / 11 \quad 37^{\circ} 05^{\prime} 01.42^{\prime \prime N} / 122^{\circ} 14^{\prime} 46.38^{\prime \prime} W^{*}$

7 M.v.v

$10 / 15 / 11 \quad 37^{\circ} 06^{\prime} 41.73^{\prime \prime N} / 122^{\circ} 15^{\prime} 33.20^{\prime \prime} \mathrm{W}$

1 M.v.f.

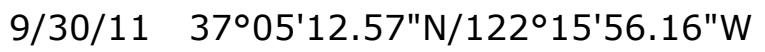

2 M.v.f.

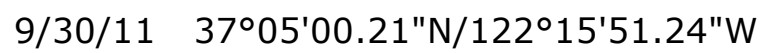

3 M.v.f.

$9 / 2 / 11$

$37^{\circ} 04^{\prime} 13.99^{\prime \prime N} / 122^{\circ} 15^{\prime} 19.59^{\prime \prime} \mathrm{W}$

3 M.v.f

$9 / 2 / 11$

$37^{\circ} 04^{\prime} 13.99^{\prime \prime N} / 122^{\circ} 15^{\prime} 19.59^{\prime \prime} W^{*}$

9 M.v.v

$9 / 10 / 11 \quad 37^{\circ} 04^{\prime} 46.18 \mathrm{~N} / 122^{\circ} 14^{\prime} 46.08 \mathrm{~W}$

M.v.v.

$3 / 4 / 12$

$37^{\circ} 05^{\prime} 11.76^{\prime \prime} \mathrm{N} / 122^{\circ} 14^{\prime} 50.38^{\prime \prime} \mathrm{W}$
274 WF slope of Big willow gulch

406 Scotts creek/s-facing roadbank

75 Scotts creek/WF brush slope

439 Scotts creek/SF rdbank near NF of Q. creek

236 WF slope above lower prarie gulch

322 Scotts creek/SEF edge of buckeye grove ridg

338 Same as above

261 WF oak woodland above Las trancas arroyo

299 See 5

197 see 5

944 Scotts creek/SF upper laird gulch

261 WF oak woodland above Las trancas arroyo

292 SF hillside, coastal scrub above washout turr

305 WF slope above Lower big willow gulch

305 WF slope above Lower big willow gulch

112 Scotts creek/rdbank above swanton rd Scotts Creek/WF ridge overlooking squirell fl 367 road 
Appendix B

Locations of plots used in experiment

\begin{tabular}{|c|c|c|}
\hline Plot & Latitude & $\begin{array}{l}\text { Longtitude } \\
-\end{array}$ \\
\hline 1 & 37.08529551 & $\begin{array}{l}122.2470895 \\
-\end{array}$ \\
\hline 2 & 37.08534403 & $\begin{array}{l}122.2471552 \\
-\end{array}$ \\
\hline 3 & 37.08655564 & $\begin{array}{l}122.2487863 \\
-\end{array}$ \\
\hline 4 & 37.08667139 & $\begin{array}{l}122.2487782 \\
-\end{array}$ \\
\hline 5 & 37.08667139 & $\begin{array}{l}122.2487782 \\
-\end{array}$ \\
\hline 6 & 37.07057627 & $\begin{array}{l}122.2555322 \\
-\end{array}$ \\
\hline 7 & 37.07056984 & $\begin{array}{l}122.2554384 \\
-\end{array}$ \\
\hline 8 & 37.07064032 & 122.2554059 \\
\hline
\end{tabular}




\section{Appendix C}

List of accessioned plants in Hoover Herbarium (OBI)

$\begin{array}{rrr}\text { Family \# } & \text { Population \# } & \begin{array}{r}\text { Accession number } \\ \text { (OBI) }\end{array} \\ 5 & 14 & 77164 \\ 6+9 & 8 & 77165 \\ 10 & 13 & 77166 \\ 7 & 6 & 77167 \\ 8 & 13 & 77168 \\ 15 & 11 & 77169 \\ 4 & 17 & 77170 \\ 11 & 15 & 77171 \\ 25 & 9 & 77172 \\ 22 & 2 & 77173 \\ 24 & 3 & 77174 \\ 17 & 17 & 77175 \\ 1+3 & 4 & 77176 \\ 13 & 12 & 77177 \\ 16 & 5 & 77178 \\ 18+21 & 1 & 77179 \\ 19 & 16 & 77180\end{array}$


Appendix D

Population mean morphology measures

\begin{tabular}{|c|c|c|c|c|c|c|c|c|}
\hline From & Pop & $\mathrm{n}$ & $\begin{array}{l}\text { pop mean hr len } \\
\text { top }\end{array}$ & $\begin{array}{l}\text { pop mean } \\
\text { LBA }\end{array}$ & $\begin{array}{l}\text { pop mean hr len } \\
\text { bot }\end{array}$ & $\begin{array}{l}\text { pop mean den } \\
\text { top }\end{array}$ & $\begin{array}{l}\text { pop mean den } \\
\text { bot }\end{array}$ & $\begin{array}{l}\text { pop mean } \\
\text { distance }\end{array}$ \\
\hline $\mathrm{F}$ & 1 & 6 & 1 & 89.83333333 & 1.166666667 & 7.310458672 & 7.062846363 & 468 \\
\hline $\mathrm{F}$ & 2 & 6 & 0.333333333 & 90 & 0.583333333 & 5.65970994 & 5.223440632 & 408 \\
\hline $\mathrm{F}$ & 3 & 6 & 1.333333333 & 90 & 1.333333333 & 7.39889164 & 7.180756986 & 328.8333333 \\
\hline $\mathrm{F}$ & 4 & 6 & 1.416666667 & 90 & 1.458333333 & 8.182997288 & 7.841056479 & 289 \\
\hline $\mathrm{F}$ & 5 & 6 & 1.125 & 92.5 & 1.125 & 5.615493456 & 5.305978069 & 290 \\
\hline $\mathrm{F}$ & 6 & 6 & 1 & 90 & 0.916666667 & 5.022992572 & 5.836575876 & 744 \\
\hline $\mathrm{F}$ & 8 & 6 & 0.5 & 90 & 0.333333333 & 9.031953779 & 5.777620564 & 1743 \\
\hline $\mathrm{F}$ & 9 & 6 & 0.5 & 117.5 & 0.291666667 & 5.223440632 & 3.932319302 & 1478 \\
\hline $\mathrm{F}$ & 11 & 6 & 0.708333333 & 96.66666667 & 0.75 & 5.305978069 & 4.174036081 & 1731 \\
\hline $\mathrm{F}$ & 12 & 6 & 0.791666667 & 94.16666667 & 0.541666667 & 4.067916519 & 3.478363401 & 2428 \\
\hline $\mathrm{F}$ & 13 & 12 & 0.875 & 87.91666667 & 0.854166667 & 8.126989742 & 8.701804033 & 3111 \\
\hline $\mathrm{F}$ & 14 & 6 & 0.5 & 90 & 0.25 & 11.908973 & 5.742247377 & 1828 \\
\hline $\mathrm{F}$ & 15 & 6 & 0.52 & 86.66666667 & 0.39 & 6.211531659 & 5.779978776 & 2264 \\
\hline $\mathrm{F}$ & 16 & 6 & 0.75 & 90 & 0.583333333 & 6.473293244 & 5.689187596 & 1742 \\
\hline $\mathrm{F}$ & 17 & 12 & 0.616666667 & 100.1666667 & 0.479166667 & 6.673741304 & 4.987619385 & 1165.5 \\
\hline G & 1 & 5 & 0.62 & 91.5 & 0.64 & 7.385921472 & 11.27697206 & 468 \\
\hline G & 2 & 3 & 0.333333333 & 93 & 0.433333333 & 13.25315411 & 18.51196793 & 408 \\
\hline G & 3 & 8 & 0.857142857 & 92.61904762 & 1.021428571 & 10.22285108 & 11.46091263 & 318.75 \\
\hline G & 4 & 4 & 1.333333333 & 99.48384615 & 1.083333333 & 6.437920057 & 6.060606061 & 289 \\
\hline $\mathrm{G}$ & 5 & 1 & 2 & 91 & 1 & 8.48956491 & 21.22391227 & 290 \\
\hline G & 6 & 2 & 1.125 & 92 & 0.9375 & 6.720905554 & 11.28404669 & 744 \\
\hline G & 7 & 3 & 0.383333333 & 93 & 0.266666667 & 7.145383799 & 10.28180639 & 2556 \\
\hline
\end{tabular}




\begin{tabular}{|l|l|l|l|l|l|l|l|l|} 
G & 8 & 5 & 0.357 & 103.8125 & 0.3125 & 5.376724443 & 6.685532367 & 1759.2 \\
\hline G & 9 & 3 & 0.3 & 100 & 0.2 & 11.86180875 & 11.93255512 & 1478 \\
\hline G & 10 & 2 & 0.5 & 95 & 0.5 & 4.598514326 & 5.836575876 & 1953 \\
\hline G & 11 & 2 & 0.4 & 105 & 1 & 3.5726919 & 3.961796958 & 1731 \\
\hline G & 12 & 2 & 0.4 & 92 & 0.4 & 3.148213654 & 5.235231694 & 2428 \\
\hline G & 13 & 4 & 0.9 & 91.5 & 0.7125 & 8.896356562 & 9.603820304 & 3111 \\
\hline G & 14 & 3 & 0.291666667 & 94.04761905 & 0.341666667 & 4.339110954 & 3.843886334 & 1828 \\
\hline G & 15 & 2 & 0.5 & 95 & 0.5 & 6.048814998 & 7.251503361 & 2264 \\
\hline G & 16 & 3 & 0.433333333 & 85 & 0.4 & 12.09763 & 19.95047754 & 1742 \\
\hline G & 17 & 6 & 0.616666667 & 105.1707317 & 0.433333333 & 7.593444169 & 6.496875369 & 1165.5 \\
\hline
\end{tabular}




\section{Appendix E}

\section{Reciprocal transplant data}

$\begin{array}{ll}\text { Region } & \text { assigned ssp. N Rows } \\ \text { C } & \text { M.v.f. } \\ \text { C } & \text { M.v.v. } \\ \text { I } & \text { M.v.f. } \\ \text { I } & \text { M.v.v. }\end{array}$

\begin{tabular}{|c|c|c|c|c|c|c|c|c|c|}
\hline 0 & 36.25 & 39.0625 & 35.78125 & 33.75 & 28.28125 & 19.84375 & 19.84375 & 10.15625 & 10.1562 \\
\hline 0 & 42.2222222 & 43.6111111 & 37.2222222 & 34.4444444 & 25 & 15.27777778 & 15.2777778 & 8.611111111 & 8.055555 \\
\hline 1.09375 & 25.4769737 & 26.8914474 & 25.9457237 & 22.6644737 & 20.0082237 & 15.3207237 & 14.6957237 & 14.8519737 & 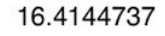 \\
\hline 3.61111111 & 23.6111111 & 22.5308642 & 21.558642 & 16.6666667 & 15.5555556 & 11.1111111 & 11.1111111 & 9.72222222 & 10.55 \\
\hline
\end{tabular}




\section{Appendix F}

Soil Data Table

\begin{tabular}{|c|c|c|c|c|c|c|c|c|}
\hline Population Objectic & & Name & Slope (Degrees) A & spect & Soil Code Soil Type & Elevation (feet) & $x$ & $\gamma$ \\
\hline & 1 & M.v.f. & 15 & SE & 146 ros Loam & 651.345337 & -122.236 & 37.0975 \\
\hline & 2 & M.v.f. & 30 & SE & 118 , Complex & 652.975525 & -122.236 & 37.09705 \\
\hline \multirow[t]{9}{*}{8} & 3 & M.v.f. & 35 & E & 118 , Complex & 767.29425 & -122.237 & 37.09574 \\
\hline & 5 & M.v.f. & 15 & SE & 146 ros Loam & 501.28064 & -122.235 & 37.09313 \\
\hline & 6 & M.v.f. & 15 & E & 113 r Complex & 445.096924 & -122.235 & 37.09171 \\
\hline & 7 & M.v.f. & 10 & s & 146 ros Loam & 438.826233 & -122.235 & 37.09136 \\
\hline & 8 & M.v.f. & 45 & E & 113 r Complex & 874.739624 & -122.237 & 37.09459 \\
\hline & 9 & M.v.f. & Unknown & Unknown & 118 , Complex & Unknown & -122.265 & 37.08691 \\
\hline & 10 & M.v.f. & Unknown & Unknown & 118 , Complex & Unknown & -122.265 & 37.08613 \\
\hline & 11 & M.v.v. & Unknown & Unknown & 118 , Complex & Unknown & -122.266 & 37.08598 \\
\hline & 12 & M.v.f. & 20 & SW & 106 amy Sand & 440.747711 & -122.261 & 37.08315 \\
\hline $18 \& 21$ & 13 & M.v.f. & Unknown & Unknown & 118 , Complex & Unknown & -122.266 & 37,08683 \\
\hline 22 & 14 & M.v.f. & Unknown & Unknown & 169 Jay Loam & Unknown & -122.264 & 37.08339 \\
\hline 4 & 15 & M.v.f. & 5 & E & 113 r Complex & 323.478394 & -122.25 & 37.07832 \\
\hline 17 & 16 & M.v.v. & 25 & E & 113 r Complex & 303.321045 & -122.25 & 37.07914 \\
\hline 25 & 17 & M.v.v. & 0 & sw & 171 juel Loam & 104.414894 & -122.246 & 37.07949 \\
\hline 19 & 18 & M.v.f. & 5 & NW & 169 Jlay Loam & 199.97699 & -122.246 & 37.08373 \\
\hline 5 & 19 & M.v.v. & 15 & SE & 118 , Complex & 313.495636 & -122.247 & 37.08598 \\
\hline 9 & 20 & M.v.v. & 55 & w & 171 juel Loam & 158.072327 & -122.249 & 37.08716 \\
\hline 6 & 21 & M.v.v. & 50 & NW & 169 Jlay Loam & 176.016617 & -122.249 & 37.0874 \\
\hline 11 & 22 & M.v.v. & 0 & SW & 168 Jay Loam & 522.583191 & -122.241 & 37.08564 \\
\hline 13 & 23 & M.v.v. & 25 & s & 113 r Complex & 422.261383 & -122.248 & 37.09716 \\
\hline 10 & 24 & M.v.f. & 25 & sW & 142 I Complex & 958.438232 & -122.238 & 37.09497 \\
\hline 20 & 25 & M.v.v. & 20 & E & 153 ) Complex & 950.373474 & -122.259 & 37.11159 \\
\hline 12 & 26 & M.v.f. & 20 & NW & 118 , Complex & 294.297913 & -122.256 & 37.07052 \\
\hline $23 \& 24$ & 27 & M.v.f. & 20 & NW & 118 , Complex & 328.540039 & -122.255 & 37.07055 \\
\hline 2 & 28 & M.v.f. & 40 & NW & 118 , Complex & 333.385742 & -122.255 & 37.07058 \\
\hline $1 \& 3$ & 29 & M.v.f. & 35 & NW & 118 , Complex & 290.181976 & -122.252 & 37.06566 \\
\hline 16 & 30 & M.v.f. & 35 & NW & 118 , Complex & 258.864471 & -122.242 & 37.05453 \\
\hline 14 & 31 & M.v.v. & 0 & $\mathrm{~N}$ & 170 zuel Loam & 64.500107 & -122.228 & 37,06457 \\
\hline 15 & 32 & M.v.v. & 35 & SE & 169 șlay Loam & 411.850555 & -122.214 & 37.04923 \\
\hline 7 & 33 & M.v.f. & 50 & NW & 169 Jlay Loam & 60.124996 & -122.222 & 37.04236 \\
\hline
\end{tabular}




\section{Appendix G}

Discriminant analysis data

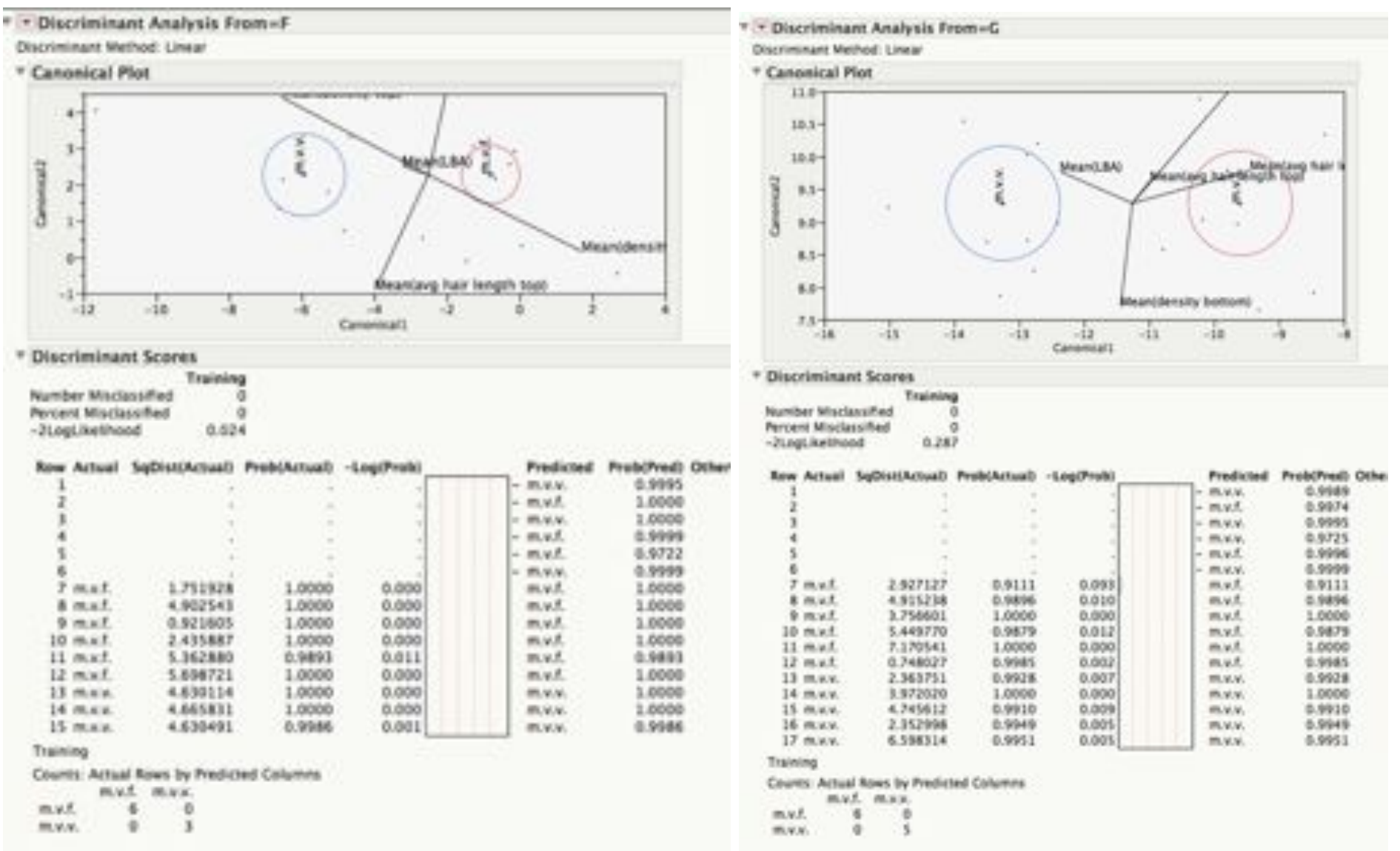

